\title{
Can We Talk About Transparency in Moroccan Public Finances?
}

\author{
Omar Taouab \\ Sara Ameur
}

Laboratory of Management sciences - IBN TOFAIL University, Morocco, Research team of Finance, Audit and Control of Organizations - ENCG

Kenitra

Doi:10.19044/esj.2018.v14n16p85 URL:http://dx.doi.org/10.19044/esj.2018.v14n16p85

\begin{abstract}
The link between good governance and better economic and social outcomes is increasingly acknowledged. Transparency - openness about policy objectives, preparation and application - is a key element of good governance. Availability of reliable, relevant and timely information about the public finances allows the government and the citizens to see clearer. Upgraded public service delivery, including the providing of education, healthcare and sanitation, depends on the transparent and efficient management of public funds. Many nations still face challenges in the effective management of their financial resources. Therefore, Transparency is considered as an income to strengthening governance.

For more than a decade, civil society organizations around the world, as well as international financial institutions, have been pushing governments to provide the public with more comprehensive budget information. The movement for greater public finance transparency has been gaining momentum in recent years; the recent global financial crisis has put even more emphasis on the importance of budget transparency. Calls for transparency, accountability, and equality have emerged in the whole world, especially the Arab world, with citizens summoning their governments to reveal their incomes and expenditures, as well as strategies and ambitions.

To contribute to these efforts, we will be studying and analyzing the reference tools proposed by the international organizations for measuring the degree of budget transparency, and we will attempt to examine the finance transparency in Morocco.
\end{abstract}

Keywords: Public finances, transparency, budget, Morocco 


\section{Introduction}

\section{'Democracy'!}

Democracy is by far the most used term in the world, and the most claimed right. It is also the most challenging form of government - for both politicians and the people-, because as the U.S. president Abraham Lincoln once defined democracy: 'it is the Government of the people, by the people, for the people'.

The term 'democracy' minimally presupposes three essential elements: transparency, accountability, and equality.

- $\quad$ Transparency symbolizes a free access to governmental political and economic activities and decisions.

- $\quad$ Accountability requires a state being held responsible, by both its people and its elected bodies, for its choices and actions.

- $\quad$ And the concept of equality includes citizens being treated equally under the law.

While some people talk about transparency, accountability and equality as separate attributes, it is evident that they are not independent. Transparency enables all stakeholders in a country to see the structure and functions of the government, its policy intentions, fiscal projections, and accounts for past periods. The main purpose of opening these windows is to render those inside, accountable and answerable for their decisions and actions. Accountability is the obligation to render an account for the responsibility conferred, and equality is the fact that all citizens are equal and have the same right of knowing what is done with their money, and the same right to make accountable the people who should be.

These legitimate requests partly reflect the implementation of the Declaration of Human and Civic Rights of 26 august 1789, which in Articles 14 and 15 considers that:

"All citizens have the right to ascertain, by themselves, or through their representatives, the need for a public tax, to consent to it freely, to watch over its use, and to determine its proportion, basis, collection and duration."

"Society has the right to ask a public official for an accounting of his administration."

Calls for transparency, accountability, and equality have emerged in the Arab world, with citizens summoning their governments to reveal their incomes and expenditures, as well as strategies and ambitions. In this paper, we will analyze one the three elements of democracy, which is 'TRANSPARENCY', and we will focus on one of the Arab world's countries, to make it as a study field 'MOROCCO'.

When we talk about public finances transparency, it's clear that we talk about the budget transparency, because the budget is the single most important policy document of governments, where policy objectives are reconciled and 
implemented in concrete terms. Budget transparency is defined as the full disclosure of all relevant fiscal information, in a timely and systematic manner.

The movement for greater budget transparency has been gaining traction in recent years. International financial institutions, credit ratings agencies, regional economic blocs, and civil society organizations have all taken up the cause, strengthening the case for budget transparency as a key governance issue and intrinsic public good. Former United States President Barack Obama has even articulated this commitment to budget transparency in his inaugural address:

"Those of us who manage the public's dollars will be held to account - to spend wisely, reform bad habits, and do our business in the light of day because only then can we restore the vital trust between a people and their government."

The recent global financial crisis has put even more emphasis on the importance of budget transparency. Some have hypothesized that a lack of transparency and oversight facilitated the growth of the country's debt, since the country's money is not well managed and controlled. At the same time, some have said that budget transparency is even more pertinent because countries around the world face lower foreign and domestic investment, aid and tax revenues, which make decisions about how to spend public money more questionable and argued.

However, if the transparency requirement has been the subject of many studies, and has been treated in length and depth in the literature, the question to ask is:

What about the reality? The transparency of public finances, is it just a theoretical concept, or is it really applied in public life? Does literature take into account social evolution and public institutions evolution?

In this paper, we aim to see to which point the propositions of the international organizations are applied in a developing country such as morocco.

This paper will be divided to three parts:

\section{I.:}

\section{Analysis framework}

\section{Theoretical background}

The government's budget is its most important policy document, where policy objectives are reconciled and concrete commitments are made. Public budgets should therefore be as comprehensive, informative, and timely as possible. 
It is equally important to be transparent with regard to budget indicators and underlying assumptions, such as fiscal projections and macroeconomic outlooks over the medium- and long-term.

International organizations have suggested some principals to follows, in order to insure the transparency of the public finances, in this paper we selected some transparency initiatives to discuss:

- The OECD (Organisation for Economic Co-operation and Development )Best Practices for Budget Transparency;

- The IMF (international monetary fund), Manual on Fiscal Transparency;

\section{The OECD initiative ${ }^{1}$}

The OECD Best Practices were issued in 2001 and are a reference tool. They support the full disclosure of all relevant fiscal information in a timely and systematic manner and provide a series of best practices in the areas of principal budget reports, specific disclosures, quality, and integrity.

\begin{tabular}{|c|c|c|}
\hline TYPE & $\begin{array}{c}\text { Report/ } \\
\text { Document }\end{array}$ & KEY REQUIREMENTS \\
\hline \multirow[t]{5}{*}{$\begin{array}{l}\text { Budget } \\
\text { reports }\end{array}$} & The budget & $\begin{array}{c}\text { It should be comprehensive, encircling all government revenue } \\
\text { and expenses. } \\
\text { The government's draft budget should be submitted to } \\
\text { Parliament in advance to allow Parliament to review it } \\
\text { properly. } \\
\text { The budget, or related documents, should include a detailed } \\
\text { commentary on the entire revenue and expenses program. }\end{array}$ \\
\hline & $\begin{array}{l}\text { Pre-budget } \\
\text { report }\end{array}$ & $\begin{array}{c}\text { It should state clearly the government's long-term economic } \\
\text { and fiscal policy objectives and intentions (for at least the } \\
\text { following four budget years and, the following two fiscal } \\
\text { years). } \\
\text { It should highpoint the total level of revenue, expenses, deficit } \\
\text { or surplus, and debt. } \\
\text { Time of release: one month prior to the introduction of the } \\
\text { budget proposal. }\end{array}$ \\
\hline & Monthly reports & $\begin{array}{l}\text { They should contain the amount of revenue and expenses in } \\
\text { each month and year-to-date. } \\
\text { Time of release: no later than the end of the following month. }\end{array}$ \\
\hline & Mid-year report & $\begin{array}{l}\text { It offers a simple and all-inclusive update on the } \\
\text { implementation of the budget (forecast of the budget outcome } \\
\text { for the current fiscal year and the following two fiscal years or } \\
\text { more). } \\
\text { Time of release: no later than six weeks of the end of the mid- } \\
\text { year period. }\end{array}$ \\
\hline & Year-end report & $\begin{array}{l}\text { This report shows conformity with the level of revenue and } \\
\text { expenses authorised by Parliament in the budget. } \\
\text { Any in-year adjustments should be exposed separately. } \\
\text { It should be audited by the Supreme Audit Institution, and be } \\
\text { released within six months of the end of the fiscal year. }\end{array}$ \\
\hline
\end{tabular}

${ }^{1}$ OECD Best Practices for Budget Transparency, 2002. 


\begin{tabular}{|c|c|c|}
\hline & & $\begin{array}{l}\text { The presentation format of the year-end report should be the } \\
\text { same as the budget presentation. }\end{array}$ \\
\hline & $\begin{array}{l}\text { Pre-election } \\
\text { report }\end{array}$ & $\begin{array}{l}\text { This report serves to clarify the situation of government } \\
\text { finances before the elections. } \\
\text { Optimally, it should be released no later than two weeks before } \\
\text { the elections. } \\
\text { It should contain the same information as the mid-year report. }\end{array}$ \\
\hline & $\begin{array}{l}\text { Long-term } \\
\text { report }\end{array}$ & $\begin{array}{l}\text { This report assesses the long-term sustainability of the } \\
\text { government's policies. } \\
\text { It should be released at least every five years, or when major } \\
\text { changes are made in revenue or expenses programs. }\end{array}$ \\
\hline \multirow[t]{6}{*}{$\begin{array}{c}\text { Specific } \\
\text { disclosures }\end{array}$} & $\begin{array}{c}\text { Economic } \\
\text { assumptions }\end{array}$ & $\begin{array}{l}\text { All key economic assumptions should be disclosed explicitly. } \\
\text { It should include: } \\
\text { the forecast for GDP }{ }^{2} \text { growth, it's composition, } \\
\text { the rate of employment and unemployment, } \\
\text { the current account, inflation and interest rates (monetary } \\
\text { policy). }\end{array}$ \\
\hline & $\begin{array}{c}\text { Tax } \\
\text { expenditures }\end{array}$ & $\begin{array}{l}\text { It's the estimated costs to the tax revenue of preferential } \\
\text { treatment for specific activities. } \\
\text { The estimated cost of key tax expenditures should be disclosed } \\
\text { as supplementary information in the budget. }\end{array}$ \\
\hline & $\begin{array}{c}\text { Financial } \\
\text { liabilities and } \\
\text { financial assets }\end{array}$ & $\begin{array}{l}\text { Borrowings should be classified by the currency denomination } \\
\text { of the debt, the maturity profile of the debt, whether the debt } \\
\text { carries a fixed or variable rate of interest, and whether it is } \\
\text { callable. } \\
\text { Financial assets should be classified by major type, including } \\
\text { cash, marketable securities, investments in enterprises and } \\
\text { loans advanced to other entities. }\end{array}$ \\
\hline & $\begin{array}{c}\text { Non-financial } \\
\text { assets }\end{array}$ & $\begin{array}{l}\text { Non-financial assets will be recognised under full accrual- } \\
\text { based accounting and budgeting. } \\
\text { This will require the valuation of the assets and the selection of } \\
\text { appropriate depreciation schedules. } \\
\text { The valuation and depreciation methods should be fully } \\
\text { exposed. }\end{array}$ \\
\hline & $\begin{array}{l}\text { Employee } \\
\text { pension } \\
\text { obligations }\end{array}$ & $\begin{array}{l}\text { Employee pension obligations are the difference between } \\
\text { accrued benefits arising from past service and the contributions } \\
\text { that the government has made towards those benefits. } \\
\text { It should be valued at market value. }\end{array}$ \\
\hline & $\begin{array}{l}\text { Contingent } \\
\text { liabilities }\end{array}$ & $\begin{array}{c}\text { Contingent liabilities are liabilities whose budgetary impact is } \\
\text { dependent on future events which may or may not occur. } \\
\text { Ex: government loan guarantees, legal claims against the } \\
\text { government... } \\
\text { They should be disclosed and classified by major category } \\
\text { reflecting their nature; historical information on defaults for } \\
\text { each category should be disclosed where available. }\end{array}$ \\
\hline \multirow[t]{2}{*}{$\begin{array}{l}\text { Integrity, } \\
\text { control and } \\
\text { accountability }\end{array}$} & $\begin{array}{c}\text { Accounting } \\
\text { policies }\end{array}$ & $\begin{array}{l}\text { A summary of accounting policies should accompany all } \\
\text { reports. } \\
\text { These should describe the basis of accounting applied (e.g. } \\
\text { cash, accrual) in preparing the reports and disclose any } \\
\text { deviations from generally accepted accounting practices. }\end{array}$ \\
\hline & $\begin{array}{l}\text { Systems and } \\
\text { responsibility }\end{array}$ & $\begin{array}{l}\text { A dynamic system of internal financial control, including } \\
\text { internal audit, should be in place to assure the integrity of } \\
\text { information provided in the reports. }\end{array}$ \\
\hline
\end{tabular}

${ }^{2}$ Gross domestic product 


\begin{tabular}{|c|c|c|}
\hline Audit & $\begin{array}{c}\text { The year-end report should be audited by the Supreme Audit } \\
\text { Institution. } \\
\text { The audit reports should be presented Parliament for scrutiny. }\end{array}$ \\
\cline { 2 - 4 } & $\begin{array}{c}\text { Public and } \\
\text { parliamentary } \\
\text { scrutiny }\end{array}$ & $\begin{array}{c}\text { Parliament should have the opportunity and the resources to } \\
\text { effectively examine any fiscal report that it deems necessary. } \\
\text { All fiscal reports referred to below should be made publicly } \\
\text { available. }\end{array}$ \\
\hline
\end{tabular}

Table $\mathrm{N}^{\circ} 1$ : The documents that should be published -OECD

\section{The IMF initiative ${ }^{3}$}

In 1998, the International Monetary Fund (IMF) presented a Code of Good Practices on Fiscal Transparency (hereafter, the Code), which led to a voluntary program of fiscal transparency assessments called fiscal transparency modules of Reports on the Observance of Standards and Codes (hereafter, fiscal ROSCs).

These developments reflected a clear agreement that fiscal transparency is a key ingredient of good governance, which has a central importance in achieving macroeconomic stability and high-quality growth. To expand and explain the principles of the Code, and to help guide the conduct of fiscal ROSCs, the first version of this Manual on Fiscal Transparency (hereafter, the Manual) was issued the same year. The IMF code was revised in 2007.

\begin{tabular}{|c|c|c|}
\hline \multicolumn{1}{|c|}{ Summary table of the documents that should be published } \\
\hline Type & Report/Document & Comment \\
\hline $\begin{array}{c}\text { Budget } \\
\text { Documentation }\end{array}$ & $\begin{array}{c}\text { The annual } \\
\text { budget } \\
\text { presentation }\end{array}$ & $\begin{array}{c}\text { Includes detailed projections of revenues, } \\
\text { expenditures, balances, and borrowing; proposed } \\
\text { fiscal measures; and appropriations accounts } \\
\text { containing details of the expenditure authorized } \\
\text { or to be authorized by the legislature through a } \\
\text { budget law. }\end{array}$ \\
\cline { 2 - 3 } & $\begin{array}{c}\text { Budget supporting } \\
\text { documents }\end{array}$ & $\begin{array}{c}\text { Includes various statements (e.g., providing } \\
\text { details of extrabudgetary funds, autonomous } \\
\text { agencies, quasifiscal activities, and fiscal risks) } \\
\text { and background papers (e.g., on the fiscal and } \\
\text { economic outlook). }\end{array}$ \\
\cline { 2 - 4 } & $\begin{array}{c}\text { Within-year } \\
\text { budget } \\
\text { reports }\end{array}$ & $\begin{array}{c}\text { Reports on fiscal outturns produced on a monthly } \\
\text { or (at least) a quarterly basis using budgetary and } \\
\text { extrabudgetary accounts and including debt. }\end{array}$ \\
\cline { 2 - 4 } & $\begin{array}{c}\text { Final } \\
\text { accounts } \\
\text { leginal audited accounts are presented to the } \\
\text { regularity and consistency with appropriations. }\end{array}$ \\
\hline Other Reports & $\begin{array}{c}\text { Financial } \\
\text { reports }\end{array}$ & $\begin{array}{c}\text { General purpose reports on the financial position } \\
\text { and performance of the government are } \\
\text { increasingly being provided. }\end{array}$ \\
\hline
\end{tabular}

Table $\mathrm{N}^{\circ}$ : The documents that should be published -IMF

${ }^{3}$ International Monetary Fund, Manual on Fiscal Transparency (2007)

${ }^{4}$ This version of the Manual (April 2007) replaces earlier drafts first posted on the IMF website in November 1998, April 1999, and March 2001. 
- Summary table of principles and basic requirements of budget transparency

\begin{tabular}{|c|c|}
\hline $\begin{array}{c}\text { PRINCIPLES } \\
\text { Responsibilities }\end{array}$ & $\begin{array}{c}\text { BASIC REQUIREMENTS } \\
\text { Policy and management roles within the public sector should be clear and } \\
\text { publicly disclosed. }\end{array}$ \\
\hline $\begin{array}{c}\text { Open Budget } \\
\text { Processes }\end{array}$ & $\begin{array}{c}\text { Budget preparation should follow an conventional timetable and be guided } \\
\text { by well-defined macroeconomic and fiscal policy objectives. } \\
\text { There should be clear procedures for budget execution, observing, and } \\
\text { reporting. }\end{array}$ \\
\hline $\begin{array}{c}\text { Public Availability } \\
\text { of Information }\end{array}$ & $\begin{array}{c}\text { Citizens should be provided with comprehensive and clear information on } \\
\text { past, current, and projected fiscal activity, and on major fiscal risks. } \\
\text { Fiscal information should be timely revealed. }\end{array}$ \\
\hline $\begin{array}{c}\text { Assurances of } \\
\text { Integrity }\end{array}$ & Fiscal data should be presented respecting the accepted data quality \\
standards.
\end{tabular}

Table $\mathrm{N}^{\circ}$ : Principles and basic requirements of budget transparency -IMF

\section{Analysis framework: the two-by two matrix ( comparison matrix)}

The purpose of this paper is to formulate best practice guidelines to ensure a proper functioning of the budget. Much of the previous research has claimed that the OECD and IMF principals are the same, in this paragraph we will try to point out the similarities and the differences between them.

We have analyzed in detail the principals, the following table sums up the work that have been done. To do so, we based our work on the process analysis framework, this process has many advantages; with its diachronic approach, it clearly displays the similarities and the differences. This approach, however, relies in many cases on the arbitrary interpretation of analysts.

\begin{tabular}{|c|c|c|}
\hline & OECD & IMF \\
\hline The documents that \\
should be published & The budget & The annual budget presentation \\
& Pre-budget report & Budget supporting documents \\
Monthly reports & Within-year budget reports \\
Mid-year report & Final accounts \\
& Year-end report & Financial reports \\
& Pre-election report & GFSM $^{5}$ reports \\
& Long-term report & \\
& Economic assumptions & \\
& Tax expenditures & \\
& Financial liabilities and financial & \\
& assets & \\
& Non-financial assets & \\
& Employee pension obligations & \\
& Contingent liabilities & \\
& Accounting policies & \\
& Systems and responsibility & \\
\end{tabular}

${ }^{5}$ Government Finance Statistics Manual 


\begin{tabular}{|c|c|}
\hline & Audit \\
\hline $\begin{array}{c}\text { The principles of } \\
\text { budget transparency }\end{array}$ & Public and parliamentary scrutiny \\
& Clarity of Roles and Responsibilities \\
& Open Budget Processes \\
& Public Availability of Information \\
& Assurances of Integrity \\
\hline
\end{tabular}

Table $\mathrm{N}^{\circ}$ 4: two-by two matrix documents required and Principles of budget transparency, $\mathrm{OECD} / \mathrm{IMF}$

Detailed comparison between the documents that should be published as required by the OECD and IMF

\begin{tabular}{|c|c|}
\hline OECD & IMF \\
\hline The budget & The annual budget presentation \\
\hline Pre-budget report & - \\
\hline Monthly reports & \multirow{2}{*}{ Within-year budget reports } \\
\hline Mid-year report & \\
\hline Year-end report & \multirow{3}{*}{ Final accounts } \\
\hline Systems and responsibility & \\
\hline Audit & \\
\hline Pre-election report & - \\
\hline Long-term report & Financial reports \\
\hline Economic assumptions & \\
\hline Tax expenditures & \multirow{5}{*}{ Budget supporting documents } \\
\hline Financial liabilities and financial assets & \\
\hline Non-financial assets & \\
\hline Employee pension obligations & \\
\hline Contingent liabilities & \\
\hline Accounting policies & - \\
\hline Public and parliamentary scrutiny & - \\
\hline
\end{tabular}

Table $\mathrm{N}^{\circ}$ : sum-up of the documents required for budget transparency, OECD /IMF

For the documents that should be published, we can say that both the OECD and IMF proposed the same documents; simply, the OECD list is more detailed than the IMF one.

As for the principles of budget transparency, there is a general agreement on the same ones. 


\section{The Moroccan case}

\section{International rankings - Open budget index}

The Open Budget Index (2005) ${ }^{6}$ provides ratings of the openness of budget material to the citizens. It is based on a detailed and systematic survey of current practice by local experts. The Index assesses:

- $\quad$ The accessibility of strategic budget documents,

- The quantity of information they provide,

- $\quad$ And the timely diffusion to citizens.

The pilot study looked at countries' performance in three main areas:

- $\quad$ Executive budget documents,

- Monitoring and evaluation reports,

- $\quad$ And public and legislative involvement in the budget process.

Drawing on internationally accepted criteria developed by multilateral organizations, the Open Budget Survey uses 109 equally weighted indicators to measure budget transparency. These indicators evaluate whether or not the government makes eight key budget documents timely available to the public online and whether these documents present budget information in a comprehensive and useful way.

Each country obtains a score (out of 100) that determines its ranking on the Open Budget Index.

Morocco's Transparency score (Open Budget Index) ${ }^{7}$ is $45 / 100^{8}$, which is near the global average score of 42 .

\section{How has the OBI score for morocco changed over time?}

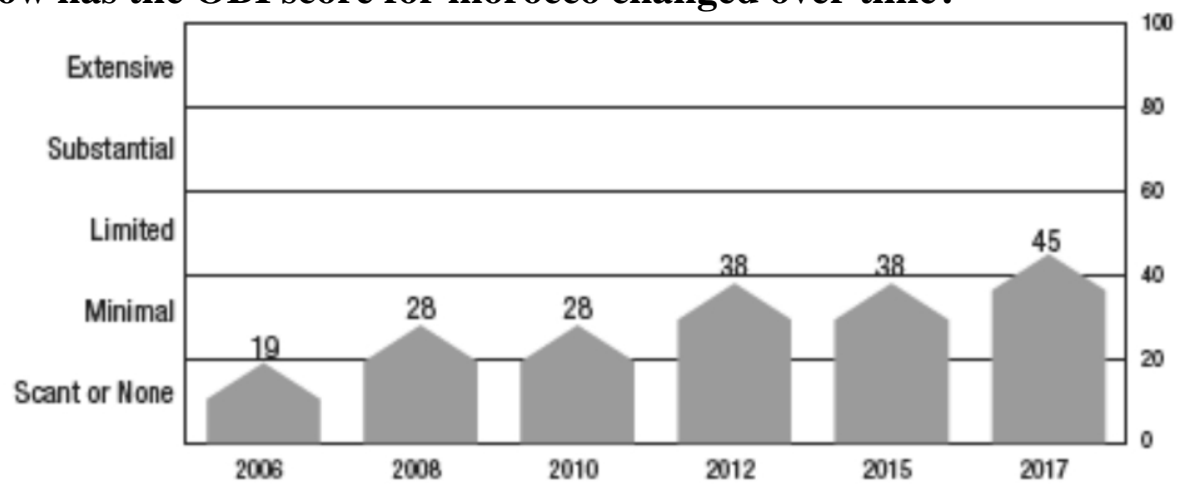

Figure $\mathrm{N}^{\circ} 1$ : Open budget index of Morocco from 2006 to 2017

We can conclude that the government's efforts on budget transparency are paying off, we can see a clear amelioration from the year 2012, which is

\footnotetext{
${ }^{6}$ Budget Transparency around the World: Results from the 2008 Open Budget Survey , By Ruth Carlitz, Paolo de Renzio, Warren Krafchik and Vivek Ramkumar

${ }^{7}$ Open budget survey Morocco 2017- international budget partnership

${ }^{8}$ limited information available
} 
the year when 'justice and development party (JDP)' got to the head of the government for the first time since its creation. It is the party that is leading the executive branch of the government of Morocco since 29 November 2011 until now; it advocates Islamism and Islamic democracy

In 2011, morocco has known an important change in the political scene, and in the way things are done. The JDP claims placing economic, legal and transparency issues at the core of its platform and is committed to internal democracy.

\section{How does budget transparency in Morocco compare to others?}

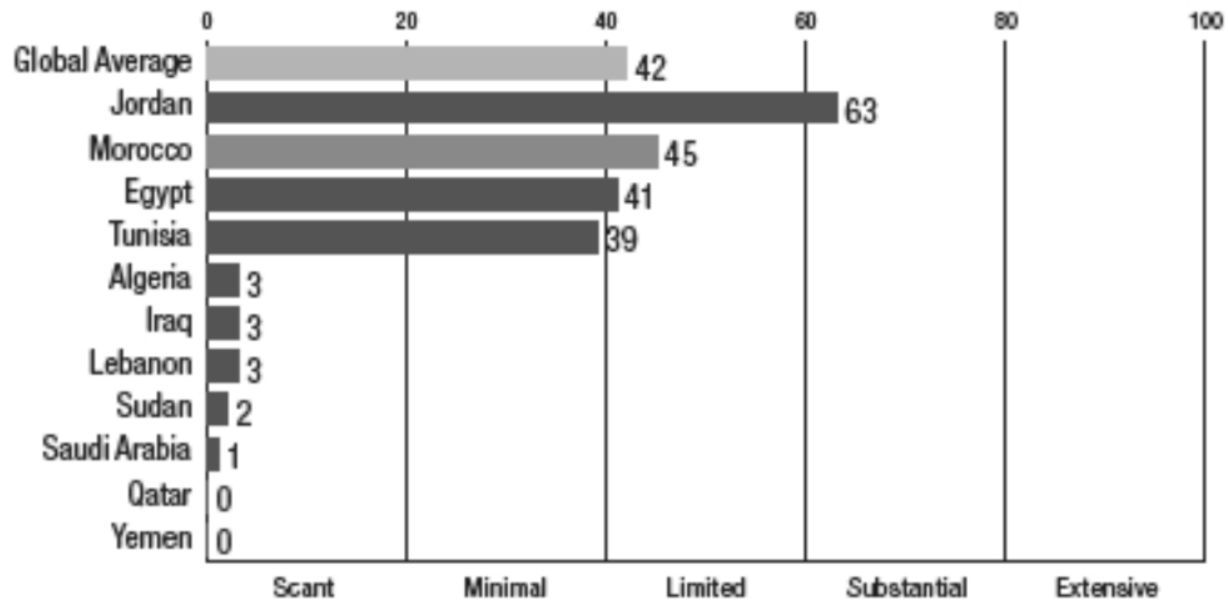

Figure $\mathrm{N}^{\circ}$ 2: comparison between the $\mathrm{OBI}$ of Morocco and the Arab countries

When we compare Morocco's score to the region's countries, which is known as a non-transparent area, we can clearly say that Morocco is taking the lead (after Jordan) on improving its budget transparency.

\section{Moroccan efforts}

The Organic Law on the Finance Law in Morocco devotes an entire chapter to the transparency ${ }^{9}$, in this chapter it is explained the following:

- The transparency of public finances is a sine qua non condition of good governance of public action.

- $\quad$ Beyond improving governance, the transparency of public finances is a major challenge for democracy.

- Its realization is based:

${ }_{9}^{9}$ Transparence, (c) Direction du Budget - Ministère de l'Economie et des Finances 2017, Published on LOF - Loi Organique relative à la loi de Finances - Maroc, Source URL: http://lof.finances.gov.ma/fr/piliers-de-la-lof/transparence 
On one hand: the adoption of new principles of public finances as the principle of the sincerity (according to which: the accounts of the State and the assumptions must be sincere),

On the other hand: the introduction of new financial rules to control the budget deficit and a better appreciation of the state's assets and financial situation.

\section{Financial rules}

The implementation of the principles of public finances indorsed by the 2018 Law on the Finance (LOF) outcomes the introduction of new financial rules relating to:

- $\quad$ The control of the budget balance;

- the rationalization of the management of state services managed autonomously;

- $\quad$ And accounting.

\section{- Budgetary balance}

The sustainability of public finances is a key factor in ensuring sustainable socio-economic development. To this end, the 2018 finance law introduced a new balanced budget rule: budget;

- $\quad$ Definition of the nature of expenses related to common expenses;

- $\quad$ Limitation of deferrals of deferred investment credits by introducing the threshold of $30 \%$ of payment appropriations;

- $\quad$ Establishment of the limitation of staff costs and integration of State social security and retirement contributions into staff costs;

- $\quad$ Consecration of the law of regulation as a finance law.

\section{- Independently Managed State Services and Treasury Special}

\section{Accounts}

Rationalization of the creation and use of autonomously managed state services, and the Special Accounts of the Treasury by:

$-$

The prohibition of the payment of an autonomously managed State service or a Special Treasury Account to a State service managed autonomously or Special Treasury Account;

- $\quad$ The determination of conditions for the creation of state services managed autonomously (30\% of own resources) and special Treasury Accounts (40\% of own resources).

\section{- Accounting}

The 2018 finance law intend to hold three types of accountabilities:

- $\quad$ the budget accounting that allows the follow-up of budget execution; 
- the general accounting that allows to evaluate the state's assets and financial situation;

- $\quad$ And the cost analysis accounting that allows to have the real cost of public policies.

\section{Principles of public finances}

In addition to the classical principles of public finance, the Organic Law on the Finance Law introduced a new principle relating to sincerity. These principles are as follows:

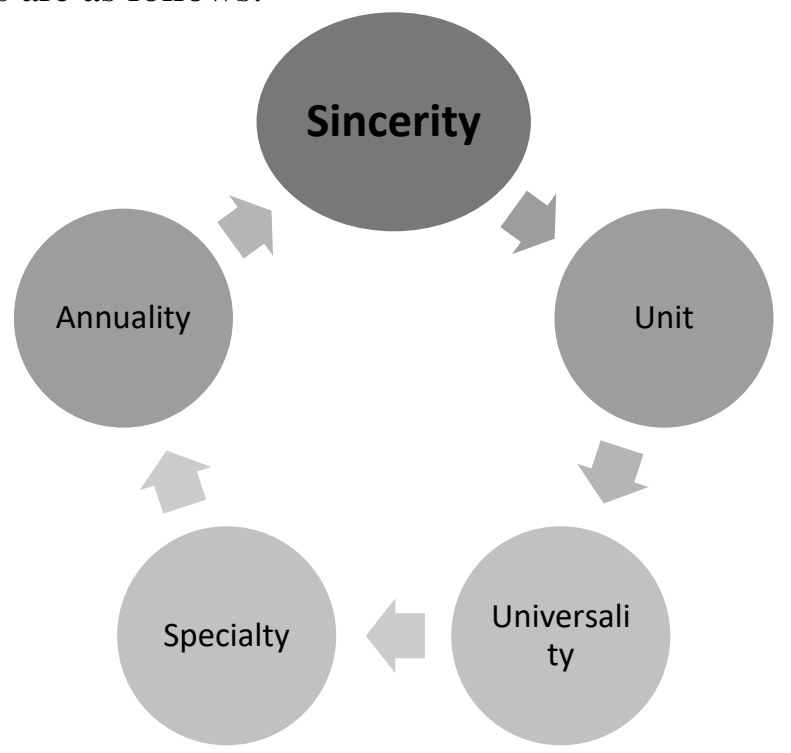

Figure $N^{\circ} 3$ : the principals of public finances in Morocco-2018

- $\quad$ Sincerity: The principle of sincerity refers to budget sincerity and accounting sincerity:
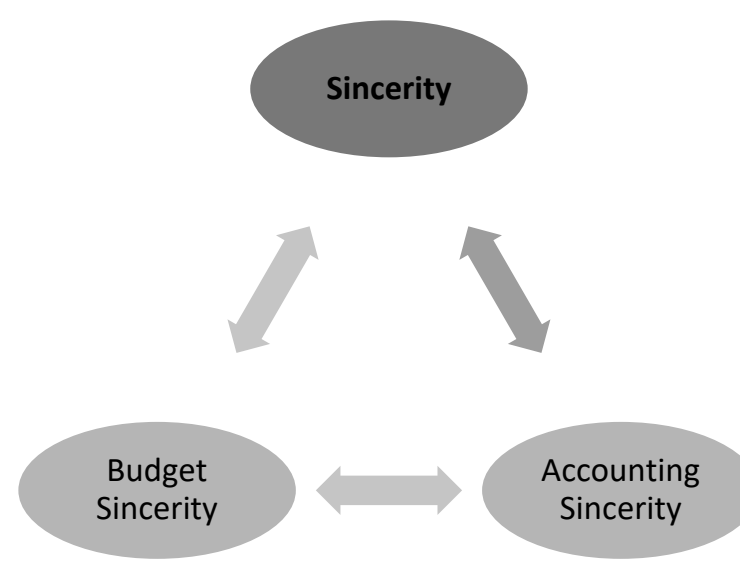

Figure $\mathrm{N}^{\circ} 4$ : the types of sincerity in public finances recommended by the ministry of finances in Morocco-2018 


\section{Budget Sincerity}

It requires the relevance of the assumptions that direct the preparation of the finance law, and the sincere presentation of all the resources and charges of the State in the finance law.

\section{- Accounting Sincerity}

Public accountants are responsible of guaranteeing the respect of accounting principles and rules by ensuring, in particular, the fairness of accounting records and the respect of procedures and the quality of public accounts. In addition, the court of auditors certifies the regularity, the sincerity and the fidelity of the public finances.

- Unit: The legislative corps ask to see all the revenues and expenditures of the State grouped in a single document, to enable it to have an accurate and global vision the state of public finances.

- Universality: Resources and expenses should be counted separately so that there is no compensating between revenues and expenditures. To have a clear overview over revenues and expenditures.

- Specialty: the Government should not have an absolute control over the authorization of expenditure; it should always go back to the parliament to get the approval of the budget.

- Annuality: The government has to report to the Parliament on a regular basis, on the use that has been made of revenues.

\section{Application, Lessons and recommendations}

\section{Application of the international standards in Morocco} The publication of budget documents in Morocco

\begin{tabular}{|c|c|c|c|}
\hline The documents & YES & NO & Comment \\
\hline The budget & $\square$ & & $\begin{array}{c}\text { The budget report/ finance law is published in December } \\
\text { of the year preceding the year in question. It is } \\
\text { supplemented by the following reports: } \\
\text { Presentation note of the draft of the 2018 Finance Law, } \\
\text { Economic and financial report, } \\
\text { Report on Institutions and Public Enterprises, } \\
\text { Report on Independently Managed State Services } \\
\text { (SEGMA), } \\
\text { Report on the Special Accounts of the Treasury, } \\
\text { Report on Tax Expenditures, } \\
\text { Report on the Public Debt, } \\
\text { Report on the results-based Budget taking into account the } \\
\text { gender aspect, } \\
\text { Report on Human Resources, } \\
\text { Compensation Report, } \\
\\
\\
\\
\text { Neport on public assets mobilized for investment, } \\
\text { Rote on the regional distribution of the investment, } \\
\text { Orientation Note of the Head of Government on the } \\
\text { Finance Law. }\end{array}$ \\
\hline
\end{tabular}




\begin{tabular}{|c|c|c|c|}
\hline Pre-budget report & & $\square$ & $\begin{array}{l}\text { A Public Finances Scoreboard was published every year } \\
\text { by the General Treasury of the Kingdom of Morocco. The } \\
\text { last Scoreboard was published in January } 2011 .\end{array}$ \\
\hline Monthly reports & $\square$ & & $\begin{array}{c}\text { Two monthly bulletins / reports are published: } \\
\text { Monthly Bulletin of Fiscal Statistics, } \\
\text { Monthly bulletin of local finance statistics. } \\
\text { These reports contain the following information: } \\
\text { The main trends of recipes, } \\
\text { The main trends in spending, } \\
\text { Treasury balances, } \\
\text { Situation of the charges and resources of the treasury, } \\
\text { Special accounts of the treasury, } \\
\text { autonomously managed state services, } \\
\text { Forecast realization rate, } \\
\text { Deficit / exceed of the treasure, } \\
\text { Financing. }\end{array}$ \\
\hline Mid-year report & & $\square$ & No mid-year-report is published \\
\hline Year-end report & $\square$ & & $\begin{array}{l}\text { A report of activity is published by the general treasury of } \\
\text { the Kingdom of Morocco, at the end of the accounting } \\
\text { year. } \\
\text { It should be noted that this report is published the month } \\
\text { of June of the following year. }\end{array}$ \\
\hline Pre-election report & & $\square$ & $\begin{array}{l}\text { The government has no legal obligation on publishing a } \\
\text { pre-election report. } \\
\text { However, in the elections of 2016, and for the first time in } \\
\text { Morocco, the government (led by the justice and } \\
\text { development party) has published a government } \\
\text { realizations report / pre-election report. }\end{array}$ \\
\hline Long-term report & & $\square$ & No long term report is published. \\
\hline $\begin{array}{l}\text { Economic } \\
\text { assumptions }\end{array}$ & $\square$ & & $\begin{array}{l}\text { Economic and financial statistics are published annually } \\
\text { by the general treasury of the Kingdom of Morocco, these } \\
\text { statistics concern the following points: } \\
\text { Indicators and monthly key figures, } \\
\text { National accounts, } \\
\text { Social indicators, } \\
\text { Sectoral activities, } \\
\text { External accounts, } \\
\text { Public finances, } \\
\text { Debt, } \\
\text { Money and credit, } \\
\text { Money market and stock market, } \\
\text { International environment, } \\
\text { Morocco's rating. }\end{array}$ \\
\hline Tax expenditures & & $\square$ & $\begin{array}{l}\text { There is no report specific to Tax expenditures; it is a } \\
\text { simple paragraph that we can found in other reports. }\end{array}$ \\
\hline $\begin{array}{l}\text { Financial liabilities } \\
\text { and financial assets }\end{array}$ & & $\square$ & $\begin{array}{c}\text { There is no report specific Financial liabilities and } \\
\text { financial assets; it is a simple paragraph that we can found } \\
\text { in other reports. } \\
\text { However we can find a payment law, published every } \\
\text { year. }\end{array}$ \\
\hline $\begin{array}{l}\text { Non-financial } \\
\text { assets }\end{array}$ & & $\square$ & No non-financial assets term report is published. \\
\hline $\begin{array}{c}\text { Employee pension } \\
\text { obligations }\end{array}$ & & $\square$ & No Employee pension obligations report is published. \\
\hline
\end{tabular}




\begin{tabular}{|c|c|c|c|}
\hline $\begin{array}{l}\text { Contingent } \\
\text { liabilities }\end{array}$ & & $\square$ & $\begin{array}{l}\text { There is no report specific to Contingent liabilities; it is a } \\
\text { simple paragraph that we can found in other reports. }\end{array}$ \\
\hline $\begin{array}{l}\text { Accounting } \\
\text { policies }\end{array}$ & $\square$ & & $\begin{array}{l}\text { All the accounting policies are defined and published, we } \\
\text { can find two types of publications: } \\
\text { Legislative and regulatory texts: } \\
\text { Public markets, } \\
\text { Territorial collectivities, } \\
\text { Taxation and recovery, } \\
\text { Public accountancy, } \\
\text { Staff costs, } \\
\text { Codes. } \\
\text { Repository: } \\
\text { History of the Moroccan budget, } \\
\text { Legal framework: Constitution, } \\
\text { Process of preparation of the project of finance law and its } \\
\text { adoption, } \\
\text { Budgetary nomenclature, } \\
\text { Organic law. }\end{array}$ \\
\hline $\begin{array}{l}\text { Systems and } \\
\text { responsibility }\end{array}$ & $\square$ & & $\begin{array}{l}\text { In every public entity, internal financial controls are in } \\
\text { place, which can be separated to two types : internal } \\
\text { control and internal audit. } \\
\text { But there is no document published to the citizens, } \\
\text { clarifying the systems and responsibilities. } \\
\text { However, there are some documents that defines the } \\
\text { systems and responsibilities, inside every organization, but } \\
\text { they are not widely and openly shared. }\end{array}$ \\
\hline Audit & $\square$ & & $\begin{array}{c}\text { The audit reports prepared by the magistrates of the audit } \\
\text { court are considered as instructional documents and are } \\
\text { more or less confidential. } \\
\text { The main recipients of the audit reports are: } \\
\text { The President of the audit court, } \\
\text { The head of the controlled organization, } \\
\text { The representatives of the State: the minister guardian of } \\
\text { the controlled establishment, } \\
\text { The General Treasurer, } \\
\text { crimes), } \\
\text { Criminal justice (in case of interference, corruption, or } \\
\text { The Court of Budgetary and Financial Discipline (if } \\
\text { unelected authorizing officers have broken laws and } \\
\text { rules), } \\
\text { The public opinion, finally, is informed. The reports are } \\
\text { available on request, accessible on CD-ROM, and, on the } \\
\text { Internet server of the financial jurisdiction. It should be } \\
\text { noted that not all audit reports are accessible to the public; } \\
\text { an annual report containing less than } 30 \% \text { of the missions } \\
\text { is published with a delay of two years. }\end{array}$ \\
\hline $\begin{array}{l}\text { Public and } \\
\text { parliamentary } \\
\text { scrutiny }\end{array}$ & $\square$ & & $\begin{array}{l}\text { The results of Public and parliamentary scrutiny are } \\
\text { always published after the count of the votes. }\end{array}$ \\
\hline Additional reports & $\square$ & & $\begin{array}{l}\text { Some additional reports are published in Morocco: } \\
\text { Citizen Budget } \\
\text { The annual citizen budget is considered a simplified } \\
\text { document of the Finance Law. It summarizes the key } \\
\text { figures, through which the citizen can determine how } \\
\text { expenditures are distributed to fund public services, as } \\
\text { well as revenues from various sources. This document also }\end{array}$ \\
\hline
\end{tabular}




\begin{tabular}{|l|l|l|}
\hline $\mid$ & $\begin{array}{c}\text { enables citizens to monitor public spending and learn } \\
\text { about the levels of the budget deficit and public debt as } \\
\text { well as the evolution of key macroeconomic indicators. } \\
\text { Studies, ex: } \\
\text { A practitioner's guide for the interregional Input-Output } \\
\text { System for Moroco, } \\
\text { Profile of the economic growth of the regions, } \\
\text { Opportunities for the development of Moroccan } \\
\text { distribution in sub-Saharan Africa, } \\
\ldots\end{array}$ \\
\hline
\end{tabular}

Table $\mathrm{N}^{\circ} 6$ : The documents that should be published by Morocco

\section{The respect of the principles of budget transparency in Morocco}

\begin{tabular}{|c|c|c|c|}
\hline The principles & YES & $\mathrm{NO}$ & Comment \\
\hline Clarity of Roles and Responsibilities & $\square$ & & $\begin{array}{l}\text { The basic requirements are being respected in morocco: } \\
\text { The government sector is distinguished (to some extend) } \\
\text { from the rest of the public sector and the rest of the } \\
\text { economy, } \\
\text { Policy and management roles within the public sector are } \\
\text { clear and publicly released, } \\
\text { revenues and responsibilities are clearly assigned } \\
\text { between different levels of government, } \\
\text { The structure and functions of government is clear, } \\
\text { The fiscal powers of the executive, legislative, and } \\
\text { judicial branches of government are well defined, } \\
\text { The responsibilities of different levels of government, } \\
\text { and the relationships between them, are clearly specified, } \\
\text { Government relationships with the private sector is } \\
\text { conducted in an open manner following clear rules and } \\
\text { procedures. } \\
\text { It is important to note out that, even if the rules are } \\
\text { clearly determined, we can find some dysfunctions in the } \\
\text { public sector system due to people's behavior } \\
\text { (overtaking, power abuse...) }\end{array}$ \\
\hline Open Budget Processes & $\square$ & & $\begin{array}{c}\text { Two mains criterions have to be, and are respected in } \\
\text { morocco: } \\
\text { Budget preparation follows a well-known timetable and } \\
\text { is guided by well-defined macroeconomic and fiscal } \\
\text { policy objectives. In more details: } \\
\text { A budget calendar is specified and adhered to, } \\
\text { Adequate time is allowed for the draft budget to be } \\
\text { considered by the legislature, } \\
\text { Fiscal targets and any fiscal rules are clearly stated and } \\
\text { explained, } \\
\text { A description of major expenditure and revenue } \\
\text { measures, and their contribution to policy objectives, are } \\
\text { provided, } \\
\text { The budget documentation includes an assessment of } \\
\text { fiscal sustainability. } \\
\text { There are clear procedures for budget execution, } \\
\text { monitoring, and reporting. } \\
\text { The accounting system provides a reliable basis for } \\
\text { tracing incomes, obligations, payments, debts, liabilities, } \\
\text { and assets. ( but it always depends on the integrity of the } \\
\text { controllers) } \\
\text { A monthly reports on budget developments are presented } \\
\text { to the legislature and the citizens. } \\
\text { Audited final accounts and audit reports, are presented to } \\
\text { the legislature and published within a year or two. }\end{array}$ \\
\hline
\end{tabular}




\begin{tabular}{|c|c|c|}
\hline Public Availability of Information & $\square$ & $\begin{array}{l}\text { The budget documentation is published, it includes the } \\
\text { final accounts, and other fiscal reports covering in a } \\
\text { general way (not in details) all budgetary and extra } \\
\text { budgetary activities of the central government. } \\
\text { Although information about the budget is available, it is } \\
\text { not sufficient and not always published at the adequate } \\
\text { time (within a year or two): } \\
\text { Statements describing the nature and fiscal implication } \\
\text { of central government tax costs, contingent liabilities, } \\
\text { and quasi-fiscal activities is not part of the budget } \\
\text { documents, as well as an calculation of some other major } \\
\text { fiscal risks. } \\
\text { The government do not publish a periodic report on } \\
\text { long-term public finances. } \\
\text { The government has no legal obligation to timely publish } \\
\text { fiscal information. }\end{array}$ \\
\hline Assurances of Integrity & $\square$ & $\begin{array}{l}\text { We can presume that Morocco respects the principle of ' } \\
\text { assurances of integrety': } \\
\text { Fiscal information is adapted to accepted data quality } \\
\text { standards, } \\
\text { Fiscal activities undergo effective internal oversight and } \\
\text { safeguards, } \\
\text { Fiscal information is externally examined. } \\
\text { Morocco has made some progress in this area, but still } \\
\text { has some efforts to make: } \\
\text { The annual budget and final accounts do not indicate the } \\
\text { accounting basis used in the compilation, } \\
\text { Ethical standards of behavior for public servants are not } \\
\text { clear and well publicized, } \\
\text { Public sector employment procedures and conditions are } \\
\text { not documented and accessible to interested parts, } \\
\text { Government activities and finances are internally } \\
\text { audited, but the audit procedures are not open to review. } \\
\text { The national audit body or equivalent organization do } \\
\text { not submit all reports, including its annual report, to the } \\
\text { legislature and publish them. Mechanisms should be in } \\
\text { place to monitor follow-up actions. }\end{array}$ \\
\hline
\end{tabular}

Table $\mathrm{N}^{\circ}$ 7: The respect of the principles of budget transparency in Morocco

\section{Lessons and recommendations}

So let us talk about ways of doing transparency better, using technology, innovation and ideas from the private sector and other countries. Transparency, when done right, can help to remove or at least reduce bureaucracy and adds efficiency.

Here are some elements to think about:

\section{- Comprehensiveness And Clarity}

The principle of budget comprehensiveness and clarity does not apply only to the preparation of the budget; it applies to all the major steps of the budget cycle (which are four):

\section{Budget preparation}

- The preparation of extra-budgetary assets should be clear in budget circulars, 
- Extra-budgetary assets should be contained within the budget documentation,

- Where total amounts of off-budget assets are not firm (e.g. in the case of tax payments), the budget should contain an estimation of value or a tradeoff analysis.

\section{Budget approval}

- Although extra-budgetary funds might not require a legislative endorsement, they should be presented to the legislature as well as the executive budget suggestion to offer a complete picture of planned expenses in line with government strategies,

- $\quad$ A policy for the extra-budgetary activity should be provided.

\section{Budget execution}

- Information on the execution of extra-budgetary funds must be accessible;

- $\quad$ The reporting should follow the same principles as general budget reports,

- $\quad$ There should be clear and transparent rules guiding the management and execution of extra-budgetary assets.

\section{Budget accountability}

- $\quad$ Accounting and auditing of extra-budgetary assets should follow the same rules and procedures as the general budget.

\section{- Comparative information}

The trend in public sector is to adopt a multi-year perspective. This includes comparability with past budgets, and an indication of future intent, under a medium-term budgeting framework.

Although in Morocco and most countries, budgets are prepared on an annual basis, it is important to take into account projections of expected revenues, the cost of programs and macro-economic forecasts in the budget documentation to allow a well informed decision-making process.

\section{- Expenditure classification}

Budget classification should follow internationally accepted standards. This allows greater transparency and comparability across countries.

At the international level, a basis for coherent budget classification can facilitate the integration of donor funds into national budgets of developing countries and thus enhance aid transparency and the effective use of foreign resources. 


\section{- Sensitivity analysis of the impact of changes in the key economic assumptions,}

It is critical to manage risk related to unpredictable changes in economic assumptions (such as interest rates and foreign exchange rate).

A sensitivity analysis allows ministries of finance to better anticipate the effects of deviation from expectations. Short- and medium-term macroeconomic projections should be realistic and tested for their sensitivity to changes. Unrealistic or overly optimistic assumptions can undermine the budget credibility and integrity.

\section{- Dynamic system of internal financial controls}

Internal financial control systems are in place to attest the correct, transparent and efficient execution of the budget. Transparent budget execution relies on an effective system that tracks revenues, expenditures and arrears, as well as assets and liabilities.

In morocco, we can clearly see that this system is not efficient. In general, internal financial control systems should monitor the orderly execution of the budget in an ethical, economical, efficient and effective manner. Internal audit services should be able to function as independent as possible from the department in which they are located. The Supreme Audit Institution should assess the independence and effectiveness of the internal financial controls system.

\section{- Availability of public reports}

Budget reports are accessible and contestable in order to promote transparency and accountability. Ministries of finance should not only make budget reports available, but also use them as part of an active strategy to educate citizens about the budget process.

In addition to making budget information publicly available in a timely manner, the presentation of the content and its accessibility is of equal importance.

By providing a 'citizens' budget' that presents the main budget decisions and aggregates expenditures in a user-friendly manner, the government enhances citizen understanding on how their tax money is being allocate. The 'Citizen Budget' was a good start, but this initiative is not well known, the government should communicate more, and let the citizens know that they have free access to public reports.

In addition, government should make an effort to engage the public in the budget process and decision-making. Especially during the budget formulation and approval stage, dialogues with civil society can contribute to a mutual understanding on priority setting, affordability and impact of various policy options. 


\section{Conclusion}

Enough has been said to show that budget transparency accountability and control are crosscutting features of all public sector financial structures and processes.

They can be boosted through a public financial management improvement program. The components of such a program would vary from country to country and from a year to another.

The first step is not to see how a particular model can be introduced into a country, but rather to analyze the existing financial management arrangements and identify the weaknesses in meeting the financial objectives of the country. That it exactly what we tried to do in this paper. We analyzed the current financial management system and tried to highlight the main weaknesses to propose some ameliorations to end-up with a new financial management system more efficient.

To sum up, transparency should be a principle behind a unified finance system, in the spirit of improvement, effectiveness and accountability. However, we all need to recognize that challenges to delivering transparency need to be addressed. We should commit to overcoming the challenges together, through sharing our collective expertise.

\section{References:}

1. Burton, M. and Stewart,M. (2011). 'Promoting Budget Transparency Through Tax Expenditure Management. A Report on Country Experience for Civil Society Advocates, Legal Studies Research'. Paper No 544, Melbourne Law School, Melbourne: University of Melbourne;

2. Clean Gov Biz Initiative. (2012). 'Public financial management: ensuring transparent budgets'. Edited by OECD;

3. Lonsdale, C. (2017). 'Why transparency and accountability should be a principle of good blended finance'. paper work published by OECD;

4. United Nations. (1789). 'Declaration of Human and Civic Rights';

5. International Budget Partnership. (2017). 'Open budget survey Morocco';

6. International Budget Partnership. (2005). 'a guide to transparency in public finances: looking beyond the budget, publication type: guides \& training materials';

7. International Federation Of Accountants. (2012). "public sector financial management transparency and accountability: the use of international public sector accounting standards';

8. International Monetary Fund. (2007). 'Manual on Fiscal Transparency'; 
9. International Monetary Fund. (1998). 'Code of Good Practices on Fiscal Transparency';

10. Levitis, J. (2009). 'Promoting State Budget Accountability Through Tax Expenditure Reporting'. Working paper published by Center on Budget and Policy Priorities;

11. Li Swift, Z. (2006). 'Managing the Effects of Tax Expenditures on National Budget'. World Bank Policy Research, Working Paper 3927 published by World Bank;

12. Ministère de l'Economie et des Finances. (2018). 'Loi Organique relative à la loi de Finances' ;

13. Marr, C. and Highsmith, B. (2011). 'Reforming Tax Expenditures Can Reduce Deficits While Making the Tax Code More Efficient and Equitable'. Working paper published by Center on Budget and Policy Priorities;

14. Petrie, M and Shields, J. (2010). 'Producing a Citizens' Guide to the Budget: Why, What and How?' Journal on Budgeting Volume 2010/2 OECD;

15. OECD. (2002). 'Best Practices for Budget Transparency';

16. OECD. (2004). 'best practice guidelines, off budget and tax expenditures'. 25th Annual Meeting of Senior Budget Officials;

17. OECD. (2010). 'Tax Expenditures in OECD Countries';

18. Public Governance Committee. (2004). 'public governance and territorial development directorate'. Working Party of Senior Budget Officials;

19. Carlitz, R. De Renzio, P. \& Krafchik, W. and Ramkumar, V. (2009). 'Budget Transparency around the World: Results from the 2008 Open Budget Survey'. paper work published by OECD;

20. Oulhem, S.\& Fasly, H. (2017). 'la transparence des finances publiques et l'équilibre des pouvoirs au Maroc (analyse sociologique)'. REMFO, N6 Octobre 2017 ;

21. Shende, S. and Bennett, T. (2004). 'Transparency and Accountability in the Public Sector in the Arab Region'. concept paper published by the United Nations;

22. World Bank. (2015). 'Transparency in Public Finance'; 